\title{
Urban Planning Aspects of Ecological and Urban Planning Regulation Fundamentals for Main Street and Road Network Functioning and Forward Development
}

\author{
Oleksiy Priymachenko \\ Kyiv National University of Construction and Architecture \\ 31 Povitroflotskyi Ave., Kyiv, Ukraine, 03680 \\ priymachenko a@ukr.net, orcid.org/0000-0001-5125-8472
}

Received on 20.05.2019, accepted after revision on 10.06.2019

https://doi.org/10.31493/uwt1921.0202

\begin{abstract}
The greatest influence of motor vehicles is manifested in the urbanized environment. The city is an indicator of sustainable development or an unfavourable relationship between motor vehicles and the urban environment. The study is based on an assessment of the impact of the vehicles current state on the street and road network and trunk road adjacent areas to substantiate the adopted planning protective measures and to determine the functional purpose of the trunk road adjacent areas proceeding from environmental impact on street and road networks. Anthropogenic air pollution sources are primarily represented by industrial enterprises and vehicles emissions.

The main task in determining the assessment of the effectiveness of the protective solutions of trunk road adjacent areas is the correct choice of assessment criteria, according to which the efficiency of solutions will differ. Since the street and road network with all its traffic flows is an integral structural element of the city, its impact on the environmental performance of the urban environment can undoubtedly be called the prevailing one.

It is necessary to highlight noise, airborne emissions and air (atmosphere) pollution among the main environmental impacts, the source of which is the functioning of the street and road network. Since the street and road system is the main tool in wastewater collection and disposal, it also has a direct impact on the ecological condition of hydrosphere objects, i.e. groundwater, springs, water bodies. Its environmental impacts on the urban setting's lithosphere are also evident: road surface contamination, lubricant residues and gasoline pollute the soil during the removal of rain and melt wastewater. It is impossible to rule out the
\end{abstract}

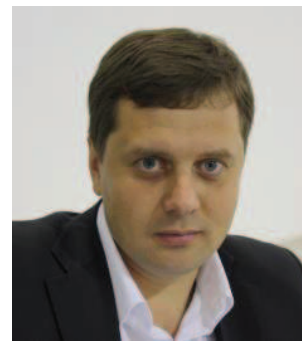

Oleksiy Priymachenko Assistant Professor of the City Urban Planning and Development $\mathrm{PhD}$, Ass. Prof.

effects of electromagnetic loads from rail vehicle operation. According to the State Statistics Service of Ukraine, the quality of atmospheric air in a modern developed city is primarily dependent on the volume of pollutant emissions, the two main sources of pollution being stationary $15 \ldots 30 \%$ and mobile $70 . . .85 \%$ (using Kyiv's example).

Key words: ecological state of urban environment, trunk road adjacent area, environmental impact.

\section{PROBLEM STATEMENT}

The purpose of this work is to explore the issues relating to the coordination of area development regulation and management processes that require research and unity of urban planning and ecological systems based on fundamental laws that are invariable and the violation of which leads to negative effects.

The development of methodological bases for regulating the functioning and development processes of the main street and road network in environmental and urban planning should be based on a comprehensive, problem- 
oriented approach and interdisciplinary approaches used in research to solve many of our time's problems. The basics of the formation of the ecological and urban planning regulation need to be searched through the development of the metropolitan setting for the scientific substantiation of the functioning and development of regulatory urban planning codes and standards.

The following research tasks are identified in accordance with the objective:

- to analyse the existing ecological and city planning models of the urban environment;

- to develop a modern model of the ecological and urban planning setting;

- to investigate the main factors of impacts and potential of pollution of the urban setting ecological system;

- to explore the impact of vehicles on the ecological state of the urban setting;

- to identify methods for reducing environmental impacts on a trunk road adjacent area;

- a model of the effectiveness of the ecological and urban planning regulation of the functioning and development of trunk road adjacent areas has been proposed to assess and predict the environmental impacts on a trunk road adjacent area.

To achieve this goal, appropriate methods were used: a systematic approach, modelling methods, analytical methods, field studies, experimental design methods, mathematical methods, graphical-analytical methods of material systematization and presentation, as well as the principles and provisions of the general system theory, system and comparative analysis.

\section{RECENT RESEARCH AND PUBLICA- TIONS ANALYSIS}

The relevance of this research topic is indicated by the analysis of scientific works and urban development codes and standards in effect. This research topic is the subject of research by renowned scientists such as:

- V.I. Nudelman, M.M. Domin, Ye.Ye. Kliushnichenko, H.I. Lavryk, M.M. Habrel, Yu.M. Bilokon, I.O. Fomin, M.M. Kushnirenko, A.P. Ositnianko, O.I. Synhaivska, A.M.
Pleshkanovska, H.Y. Filvarov in urban and territorial planning issues;

- B.V. Solukha, M.M. Osietrin, Ye.O. Rejtsin, D.S. Samoilova, V.I. Huk, T.O. Shilova, M.S. Fishelson, M.S. Murza, A.Ya. Tulaieva, H.L. Karaban, Z.I. Aleksandrovska, Yu.L. Shevchenko, V.S. Weinberg, I.B. Solukha, O.S. Furmanenko, I.I. Ustinova etc. in theoretical and scientific-methodical system studies in the aspect of transport and ecological problems.

\section{STATEMENT OF BASIC MATERIAL}

Environmental pollution is a complex process with different structural features and action parameters to generate different environmental impacts. The information model has been plotted with the classification of the pollution structure in the urban setting for the study of ecological and urban planning processes (Fig.1). According to this model, pollution impacts in the urban environment are classified by the following features:

- pollution sources;

- impact assessment;

- occurrence rate;

- exposure duration;

- pollution components;

- the parameters of effect on the urban environment;

- labour-intensive measures taken to eliminate pollution effects;

- complexity of such events' organization;

- external factors' effects.

In turn, two types of origin were proposed to distinguish pollution sources in the urban environment: communication and area-specific (Fig.2).

Communication pollution sources which are the facilities of the city's street and road network, should include all traffic flows, vehicles and mechanisms. Area-specific pollution sources are separate functional areas of the city (industrial, municipal, commercial). According to the impact assessment, pollution is divided into ultimately hazardous, highly hazardous, moderately hazardous, acceptable and safe. 


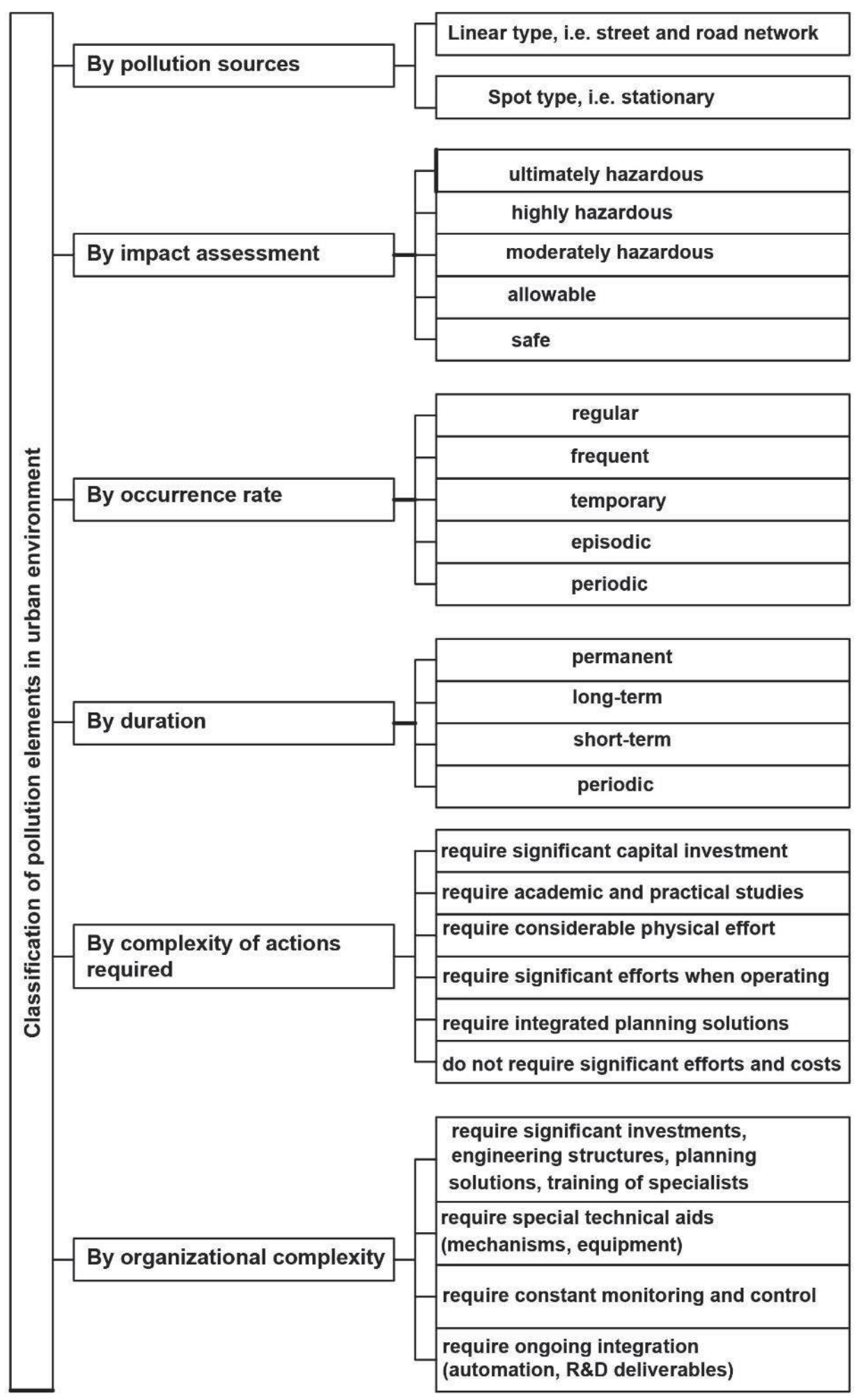

\section{ENVIRONMENTAL POLLUTION COVERAGE AREA}

\begin{tabular}{|l|}
\hline atmosphere \\
\hline hydrosphere \\
\hline lithosphere \\
\hline
\end{tabular}

EMISSIONS PHYSICAL STATE

\begin{tabular}{|l|}
\hline solid \\
\hline liquid \\
\hline gaseous \\
\hline
\end{tabular}

Fig. 1. Classification of pollution elements in the urban environment 


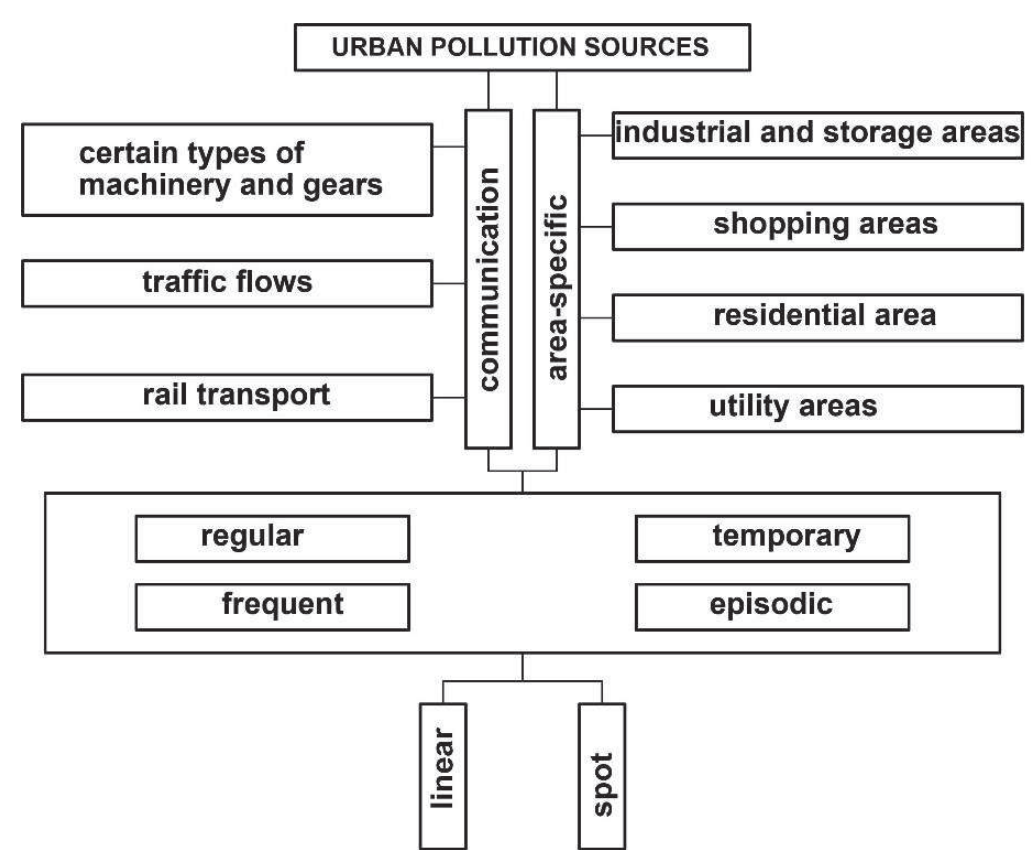

Fig. 2. Block diagram of the classification of urban pollution sources

The results of the completed study allow us to formulate the consequences of pollution impacts on the urban environment:

- environmental pollution is a process of undesirable material costs, energy, labour, means and funds that people invest in the construction and planning of the area, which in turn become the irrecoverable waste that pollutes the urban environment;

- pollution results in irreversible damage to both individual ecological systems and the biosphere as a whole, including the impact on global physical and chemical parameters of the environment;

- fertile land is lost, ecological system the entire biosphere productivity are decreased as a result of pollution;

- pollution directly or indirectly leads to deterioration of physical and moral state of a person as the main production link of a society.

The developed information models indicate the complexity of the processes occurring in the planning structure of the city.

Formalized multistage representation of the object of study of the main street and road network allows to understand clearly the process of formation of certain environmental loads, their physical and chemical condition, and indicates the management methods to reduce environmental impacts on an area in question.

In general, it is possible to work out a matrix of factors influencing the environmental impact on the street and road network based on the completed studies and the systemstructural analysis (Fig.3).

It is necessary to distinguish noise and gas air pollution in the atmosphere among the main

the functioning of a street and road network. Since the street and road system is the main tool in wastewater collection and disposal, it also directly affects the ecological state of hydrosphere objects, i.e. groundwater, water sources, and water bodies. Its environmental impact on the urban lithosphere is also evident: contaminated road surface, remains of lubricants and gasoline pollute the soil during the removal of rain and melt wastewater.

The need to develop a set of methods for managing and developing the ecological condition of urban environment is proven by analysing modern data on emissions from motor vehicles. It is also evident that as a result of the city's main concentration of traffic flows, the main street and road network areas are under the major influence. The degree of at- 
mospheric

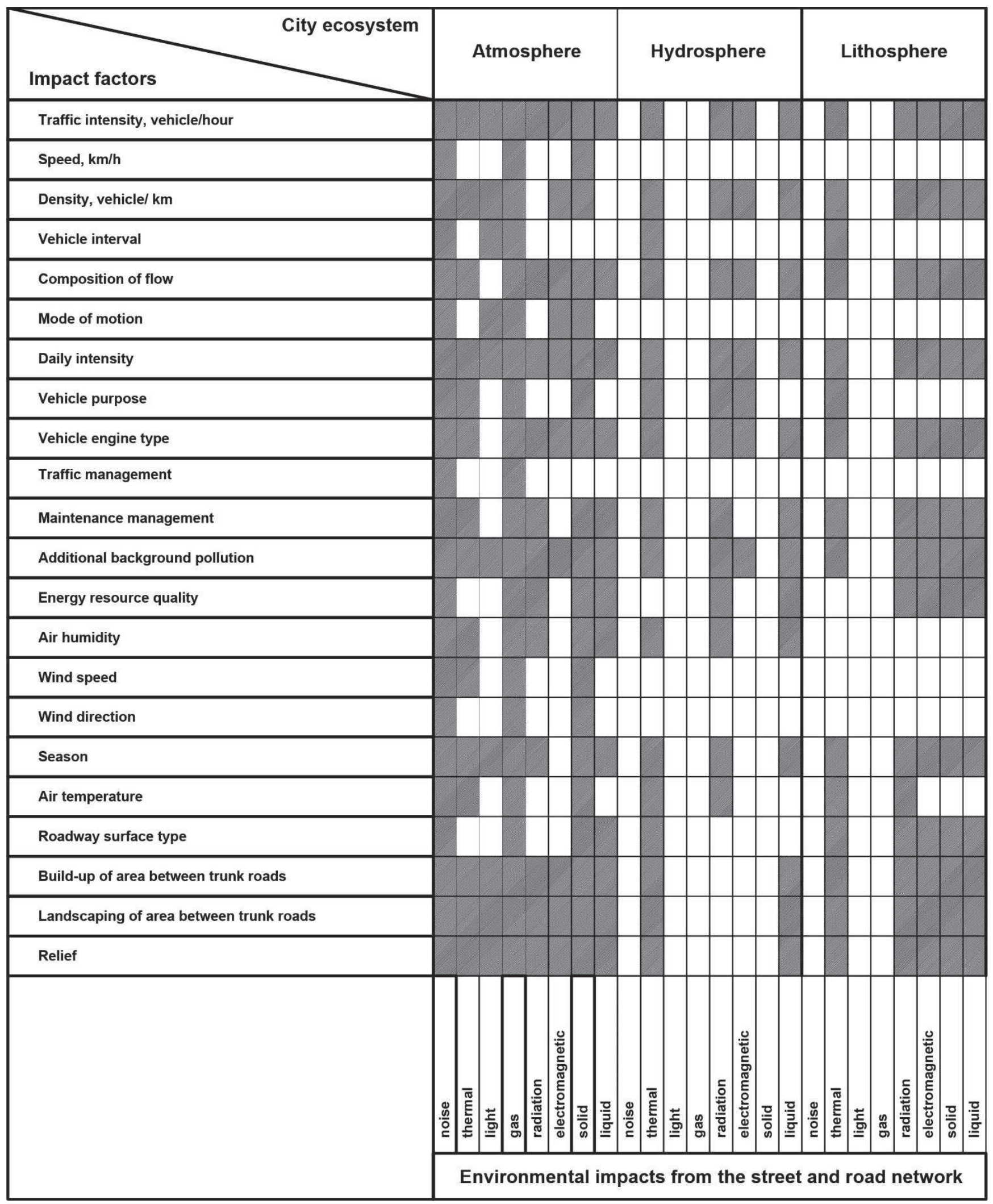

Fig. 3. The matrix of factors influencing the environmental impacts on a street and road network 
air pollution caused by vehicle emissions in local areas depends on the possibility of transferring pollutants, their level of chemical activity, meteorological distribution conditions in the area, and underlying surface characteristics. Numerous chemical reactions with different reaction rates, time of existence of all the substances involved, different dependencies of turbulent diffusion coefficients on the properties of the underlying surfaces, and certain hydrometeorological processes may occur in a limited space. The complexity of reliable modelling of automotive emission processes spread in the atmosphere therefore arises.

The approach that has been researched and proposed before for determining the EPI (ecological planning indicator) with its multifactorial content (value), on the determination of the elements and factors of influence on its action potential, will lead to the possible use of this EPI indicator by experts as an indicator of compliance of existing planning and design solutions with the regulatory planning support of the area, identifying environmental damage cases due to their direct effect, the investment volume to reduce the extent of environmental impacts, which in turn will affect the value of land and its functional efficient use. To evaluate the planning solutions enacted and the measures to reduce the EPI indicator, a model was proposed to streamline the use of trunk road adjacent areas, streamline the engineering solutions enacted, appropriately take into account a deterrent factor in countering the potential environmental impact, and determine the optimum protective measures for the area in the form of an optimum efficiency indicator formula:

$$
\begin{gathered}
E o p t=E P I(R m ; N n) \\
\text { provided that } R m->\max ; N->\min N n,
\end{gathered}
$$

where Eopt is the optimum quality of protective measures; EPI is the ecological planning indicator; $R m$ is the coverage of civil construction protective measures; $N n$ is the set of types of civil construction protective measures.

The calculation of the minimum impact on the area, which allows the use of $\mathrm{Nn}$-type protective measures, is given by the method of inverse action potential of the selected optimum protective measure to counteract the spread of environmental impact.

The studies that have been completed for the spatial arrangement of trunk road adjacent areas allow us to highlight a number of features:

- a differential approach to urban areas protection methods;

- area spatial planning optimization;

- functional and applying the trunk road adjacent areas;

- optimization of site preparation during planning and construction;

- a differential approach in the city's street and road network routing.

As a result of the research conducted and the developed scientifically based models, a system of interrelated criteria and factors influencing the formation of the urban area has been created as a set of methods for plotting the Ecological and Urban Planning Regulation Fundamentals for the functioning and forward development processes of the main street and road network (Fig.4).

The creation of the city's ecological framework should therefore take into consideration all the components of planning solutions, reflecting an effective scientific and technical justification for implementing and resolving the relevant challenges within the urban planning sector, one of which is creating a population-friendly (proper quality) environment and maintaining its continued effective upgrades.

\section{CONCLUSIONS}

Using the experience of theoretical and practical advances in urban and spatial planning the models have been developed in the study to ensure the effectiveness of regulating the ecological and urban planning status of adjacent areas of trunk road adjacent areas. A model of providing the Ecological and Urban Planning Regulation Fundamentals for the functioning and forward development processes of the main street and road network, taking into consideration the environmental impacts and forecasts, has been de- 


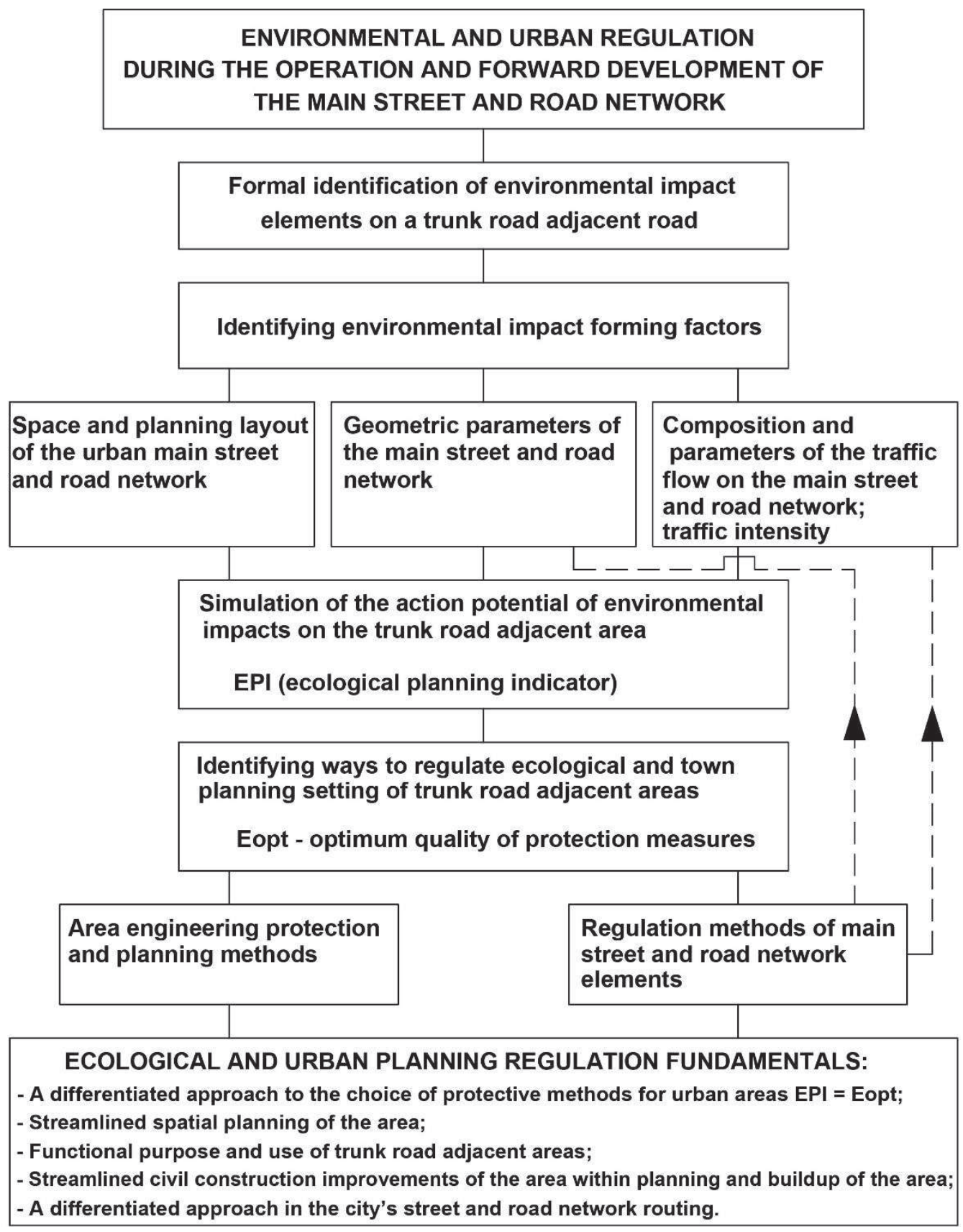

Fig.4. A model of providing the Ecological and Urban Planning Regulation Fundamentals for the functioning and forward development processes of the main street and road network

veloped based on the planning solutions enacted, with the functional purpose of the area and the choice of civil construction protective measures for the area pointed out.

Studies of the trunk road adjacent areas, taking into account the ecological and urban planning aspect, will ensure the viability of their further functional use, the formation of the city's main motor transport corridors in the context of the development of new infrastruc- ture and the reconstruction of the city's main road and road network, and identifying the economic efficiency of urban planning design solutions.

\section{REFERENCES}

1. State Construction Norm 360-92. City and City Planning. Planning and Development of Urban and Rural Settlements. Kyiv, Derzhbud Ukrainy, 113 (in Ukrainian). 
2. General Planning Scheme of Kyiv for the period through to 2020, 2001. Main Principles, 69 (in Ukrainian).

3. Solukha B.V., Fuks H.B., 2003. Urban Ecology. Kyiv, KNUCA, 337 (in Ukrainian).

4. Furmanenko O.S., 1991, City and Country Cleaning and Refuse Disposal. Kyiv, Budivelnyk, 144 (in Ukrainian).

5. Astern M.M., Solukha B.V., Shilova T.O., 2010. Environmental Evaluation of City Main Road Crossings on Different Levels. Kyiv, KNUCA, 108 (in Ukrainian).

6. Ustynova I.I., 2016. Methodological Framework of Sustainable Development of Environmental City Planning Systems. Synopsis of a thesis, Kyiv, KNUCA, 46 (in Ukrainian).

7. Solukha I.B., 2016. Methods of Urban Environmental Evaluation of Traffic Planning Hubs in Trunk Road Networks of Large Cities. Synopsis of a thesis, Kyiv, KNUCA, 22 (in Ukrainian).

8. Igor Solukha, 2015. The influence of longitudinal slope of main road carriage-way on the mass emission from road transport in the atmospheric air, MOTROL, Vol.17, No.8, 4551.

9. Annual Abstract of Statistics of Kyiv city, 2011. State Statistics Service of Ukraine, 467 (in Ukrainian).

10. Annual Abstract of Statistics of Kyiv city, 2015. State Statistics Service of Ukraine, 434 (in Ukrainian).

11. Osytnianko A.P., 2005. Kyiv Development Planning. KNUCA, 385 (in Ukrainian).

12. Priymachenko O.V., 2014, Determining the Planning Measures for Noise Reduction in the Areas Surrounding Main Roads. City and Land-Use Planning: Collection of scientific and technical articles. Kyiv, KNUCA, Iss.51, 469-474 (in Ukrainian).

13. Priymachenko O.V., 2014. Analysis of Models of Noise Propagation in Space. City and Land-Use Planning: Collection of scientific and technical articles. Kyiv, KNUCA, Iss.53, 435-439 (in Ukrainian).

14. Igor Solukha, 2015. Intersectional junctions of the main roads in city SRN System (on the basis of Kyiv SRN system). MOTROL, Vol.17, No. 8, 53-59.

15. Ivanov V.N., Storchevus V.K., 1990. Ecology and Automobilization. Kyiv, Budivelnyk, 129 (in Russian).

16. State Construction Norm B.2.3-5-2001, Streets and Roads of Urban and Rural Settlements, 2001. Kyiv, 50 (in Ukrainian).
17. State Sanitary Rule 173-96, 1996. State Sanitary Rules of Planning and Development of Settlements. Kyiv, Ministry of Healthcare of Ukraine, 84 (in Ukrainian).

18. Guidelines on Development of the Chapter of Environmental Protection, Project to Construction Norms and Regulations, 1989. 1.02.01-85,. Moscow, TSNII Proekt Gosstroya SSSR, 187 (in Russian).

19. State Construction Norm A.2.2.1-2003, 2003. Composition and Content of the Materials of Evaluation of Environmental Pressures (EEP) in Designing and Building Enterprises, Houses and Constructions. Main Principles of Design. Kyiv, Derzhbud Ukrainy, 19 (in Ukrainian).

20. State Construction Norm B.1.1-31:2013, 2003. Protection of Territories, Houses and Constructions from Noise. Kyiv, Minrehion Ukrainy, 75 (in Ukrainian).

21. State Standard of Ukraine DSTU-H B B.1.133:2013, 2003. Directive on Engineering and Design of Noise Protection of Residential Areas. Kyiv, Minrehion Ukrainy, 42 (in Ukrainian).

22. Ustynova I., 2015. Theoretical principles of wave urbanistics. Underwater Technologies, Vol.01, 33-42.

23. Shilova T.O., 2005. Analysis of acoustic conditions in Kyiv. City and Land-Use Planning: Collection of scientific and technical articles. Kyiv, KNUCA, Iss.20, 392-396 (in Ukrainian).

24. Bystriakov I.K., Shilova T.A., 1991. Estimation of paths of transport noise propagation when designing territorial integrated nature preservation systems. Abstracts of the reports of the All-Union Scientific and Technical Conference "Improvement of City Acoustical Environment: Development and Construction Methods". Sevastopol, 22-24 (in Russian).

25. Priymachenko O.V., 2017. Model for effectiveness evaluation of planning measures for protection of areas surrounding main roads from the influence of environmental pressures on the Kyiv main road network. Underwater Technologies, Vol.05, 67-73.

26. Osypova H.L., 1993. Noise protection in city planning. Designer Handbook. Stroyizdat, 96 (in Russian).

27. Samoiliuk E.P., Denysenko V.I., Pylypenko A.P., 1981. Noise control in population aggregates. Kyiv, Budivelnyk, 144 (in Ukrainian). 
28. Priymachenko O.V., Shilova T.A., 2017. Determination of limits for acoustical pollution from main roads at the stage of urban area zoning. Underwater Technologies, Vol.07, 49-56.

29. Priymachenko O.V., Kobzar O., 2018. Methodology of studies for selecting engineering decisions in territory planning International scientific journal. Transfer of Innovative Technologies, Vol.1(1), 17-25.

\section{Градостроительные аспекты обеспечения оснований эколого-градостроительного регулирования процессов функциониро- вания и развития магистральной улич- но-дорожной сети}

\section{Алексей Приймаченко}

Аннотация. Рассмотрены основные проблемы, связанные с исследованием и разработкой методологических основ экологоградостроительного регулирования процессов функционирования и развития магистральной улично-дорожной сети под влиянием экологических нагрузок.

В наибольшей степени влияние автотранспорта имеет проявление в урбанизированной среде. Город является индикатором устойчиво- го развития или неблагоприятной взаимосвязи автотранспорта и урбанизированной среды. В основу исследования положена оценка влияния современного состояния автотранспорта на улично-дорожную сеть и на примагистральную территорию для обоснования принятых планировочных мер защиты, определения функционального назначения примагистральных территорий в соответствии с экологическими нагрузками, которые возникают на улично-дорожной сети. Техногенные источники загрязнения атмосферного воздуха представлены, главным образом, выбросами промышленных предприятий и автотранспорта.

Главной задачей в определении оценки эффективности планировочных решений защиты примагистральных территорий является правильный выбор критериев оценки, согласно которым эффективность решений будет отличаться. Поскольку улично-дорожная сеть со всеми ее транспортными потоками является неотъемлемым структурным элементом города, ее влияние на экологические показатели городской среды бесспорно можно считать доминирующим.

Ключевые слова: экологическое состояние городской среды, магистральные территории, экологические нагрузки. 